\title{
Agricultural subsidies in the United States and their effect on two annual Chilean crops: corn and wheat
}

\author{
José Díaz Osorio* \\ Roberto Jara Rojas**
}

\begin{abstract}
The development strategies for Chile have been oriented toward a greater commercial openness. Chile and the United States signed a Free Trade Agreement (FTA) that has triggered controversies between producers directed to the internal market due to the production and export subsidies that this country carries out. This study analyzed the effect of subsidies granted by the United States to wheat (Tritricum aestivum) and corn (Zea mays) growers (Farm Bill 2002). For the study, Technical Standard sheet were drawn up, from which were determined the direct production costs and the gross margins. The variables used (market prices, subsidies, freight costs and tariffs) and determining the average variable costs allowed us to do a sensitivity analysis, thus establishing the minimum level of production that national farmers must achieve in order to maintain competitiveness while a free trade is in force. The signing of a trade agreement could provoke the eventual withdrawal of many Chilean producers from the business arena while at the same time, favoring consumers with lower prices for the goods derived from these grains.
\end{abstract}

Key words: Subsidies, Protectionism, Traditional Crops, Free Trade Agreement, competitiveness

* Professor do Departamento de Economia Agrária da Universidad de Talca, Chile. jdiazoso@utalca.cl

**Departamento de Economia Agrária, Universidad de Talca, Chile. rjara@utalca.cl 
JEL Classification: Q 18

\section{Introduction}

A country with a limited internal market such as that of Chile requires an active participation in the international market in order to maintain a sustained rhythm of growth. Approximately $50 \%$ of the goods and services that are transacted in the country in one year form part of Chile's foreign trade (Pro Chile, 1995). In agreement with the policy of international insertion propounded by Chile, the country has underwritten in the last decades various multilateral or bilateral agreements tending to generate a gradual commercial openness, translating into a reduction of tariffs or custom duties. As of 2002, and after a long and difficult negotiation, Chile and the United States signed, in 2003, a Free Trade Agreement, which came into effect in 2004 (Silva, 2003).

This fact has far reaching consequences given that an agreement has been signed with the main economic power in the world, which signifies access to a market of 284 million people with a high power of consumption and a per capita GDP reaching US\$35,300 (ODEPA, 2003). However, this event has generated more than one controversy, especially in the traditional agricultural sector of our country. Without a doubt the main discussion is about the effect that the American government's agricultural subsidies will have on Chilean agriculture, specifically on the so-called traditional crops. As a result of this new development, the objective of this study is to quantify the effect of certain types of farm subsides granted by the U.S. on traditional crops in Chile, measured through the production of two important grains.

\section{The farming sector in the United States}

According to the information from the World Trade Organization (WTO, 2000) the U.S. is the biggest importer and exporter in the world given that it alone has $12 \%$ of the world trade. By comparison, Chile participates in only $0.2 \%$ of the world trade.

According to the American Agricultural Census, the most relevant aspects of this sector would be:

- Of the 377.09 million arable hectares, 174.48 million are dedicated to annual crops and fruit (47.3\%). 
- Under a system of special programs for annual land retirement (Acreage Reduction Program), there are 11.93 million hectares in fallow (3\%).

- Forestry occupies a surface area of 28.92 million hectares.

- Land for haying or grazing amounts to a surface area of 160.92 million hectares.

- The average size of farming operations is about 197.09 hectares.

\section{The United States Farm Bill 2002}

The new American agricultural law, Farm Security and Rural Investment Act, was passed the $13^{\text {th }}$ of May in 2002, and replaced the FAIR Act of 1996. The application of this law came into force in 2002 and will extend until 2007 (Methol, 2002). This bill, reaching at $\$ 248.6$ billion dollars, means an $80 \%$ increase in agricultural subsidies over those of the FAIR Act of 1996 (Mittal, 2002).

The principal objectives of this law are:

- To generate adequate income for farmers.

- To supply food at reasonable prices

- Maintain a competitive international position.

- Support the conservation and protection of the environment.

- Maintain the viability of the product industry.

- Maintain an adequate level of reserves in case of production problems.

- Reach all the previous objectives at the lowest possible cost to the American government.

Although the new law is organized in ten Titles, only the first three (Commodities Program, Conservation and Trade) have direct impact on the trade of agricultural goods (Basco, 2002). The same author indicates that the most important title and the one to which the greater part of the budget is assigned, is the Commodities article. This includes diverse support programs for the following products: wheat, corn, rice, sorghum, barley, forage crops, oats, soybeans and cotton.

The Commodities Programs are:

- Guaranteed Loan Rates

- Compensatory Payments 
- Fixed or Direct Payments

- Guaranteed Real Price

- Target Price

- Counter-cyclical Payments

The guaranteed loan rate and fixed payment plans existed in the 1996 law, consequently the most relevant change is the counter-cyclical payment program that reestablishes target prices with the objective of maintaining the income of the producers.

While the Farm Bill of 1996 established maximum annual amounts of direct payments, the new agricultural law does not. The direct payments vary between US $\$ 5.8$ billion in 1998 and 4 billion in 2002 of which nearly $85 \%$ of these amounts were distributed among wheat (26 $\%)$, corn (46\%), and cotton (12\%). Nevertheless, the new Farm Bill establishes specific amounts per ton of produce. That is to say, there is no established total annual maximum amount of aid, but rather;-it depends on the levels of production (Basco, 2002).

\section{Economic relations between Chile and the United States}

Trade negotiations bring together two countries that are significantly unequal in terms of size, economic development and political power. This inequality is expressed in the first place by the per capita income (US\$ 35,300 in the U.S. versus US\$ 4,500 in Chile). In the second place, although the U.S. is the number one trade partner of Chile, our country occupies the $38^{\text {th }}$ place among the U.S. foreign trade partners.

The trade balance between the two economies presents a historically unfavorable deficit for Chile even though in the last two years, this situation has turned around (see Table 3).

Chilean exports to the U.S. come principally from the exploitation of natural resources. In 1996, the $37.3 \%$ of these exports came from raw materials and $55 \%$ from natural resources with some level of processing. These percentages did not change significantly during the nineties and the beginning of the year 2000. During 2002, raw materials represented $31 \%$ of the total exports while processed natural resources reached $59.1 \%$. As of this year, industrial goods have maintained a 7$10 \%$ part of the total exports to the U.S. On the other hand, the exports 
from the U.S. to Chile are principally made up of intermediate goods such as petroleum, lubricants and other fuels. In 1996, these represented $51 \%$ while in 2001 they reached $53 \%$ of the imports. Capital assets participated in 1996 with $40 \%$ of total imports and in 2001 this amount decreased to $38 \%$ (Silva, 2003).

Table 3 - Trade Balance between Chile and the U.S., 1996-2002 (nominal millions of US dollars)

\begin{tabular}{|l|c|c|c|c|c|c|c|}
\hline & $\mathbf{1 9 9 6}$ & $\mathbf{1 9 9 7}$ & $\mathbf{1 9 9 8}$ & $\mathbf{1 9 9 9}$ & $\mathbf{2 0 0 0}$ & $\mathbf{2 0 0 1}$ & $\mathbf{2 0 0 2}$ \\
\hline $\begin{array}{l}\text { Chilean exports to the } \\
\text { United States }\end{array}$ & $1,944.7$ & $2,075.2$ & $1,926.9$ & $2,327.8$ & $2,360.3$ & $2,581.1$ & $2,687.0$ \\
\hline $\begin{array}{l}\text { Chilean imports from } \\
\text { the United States }\end{array}$ & $2,917.6$ & $3,165.6$ & $3,163.9$ & $2,245.5$ & $2,495.4$ & $2,254.7$ & $1,958.4$ \\
\hline Trade balance & -972.9 & $-1,090.4$ & $-1,237.0$ & 82.3 & -135.1 & 326.4 & 728.6 \\
\hline
\end{tabular}

Source: Silva, 2003, with information from the Banco Central de Chile, based on reports from the National Customs Service. (Servicio Nacional de Aduanas).

\section{Chile - U.S. Free Trade Agreement: case history for wheat and corn}

In overall terms, at the end of twelve years $100 \%$ of the trade between Chile and the U.S. will be free. However, it is important to mention that a large percentage of products will be able to be traded without tariffs as soon as the FTA comes into force.

With respect to imports, $88.5 \%$ of the American products will immediately have lowered tariffs and, in the case of Chilean exports, $87 \%$ of the products will be able to enter on the American market in the same manner.

Concerning the farming sector, $87 \%$ of the produce exported by Chile will remain with zero tariffs at the moment of confirming the treaty while only $62 \%$ of the products sent to our country from the U.S. will obtain this freedom from duties (ODEPA, 2003).

For wheat, the main supplying countries in order of importance are: the United States, Argentina and Canada. In order to export wheat to Chile, these countries are currently subject to an ad valorem tariff of $8 \%$, to which must be added the specific right or from which must be 
subtracted the discount in accordance with the current price list. However, with Argentina there is a Chile-MERCOSUR trade agreement that will allow the entrance of this commodity free from the ad valorem tariff only in 2014. As for Canada, the signing of the FTA with Chile will allow the free entrance of this grain as of the year 2014 (ODEPA, 2001). In agreement with the treaty with the U.S., the tariff reduction corresponds to a non linear type in 12 years, from a tariff of $31.5 \%$ (consolidated maximum in the WTO). In the following four years, the tariff is reduced to $21 \%$ to later become duty free (Ministerio de Economía, 2002).

Concerning corn, the principal suppliers are Argentina and the U.S. For the first country there is a real tariff of $4 \%$ but in accordance with the agreement Number 35 Chile-MERCOSUR, corn will enter duty free as of 2006. On the other hand, corn coming from the U.S. is subject to a tariff of $8 \%$, but when the FTA comes into force, corn will immediately be totally duty free (ODEPA, 2001).

\section{Objectives}

\section{General Objective}

- To quantify the effect that applying American agricultural subsidies has on two Chilean agricultural products, wheat and corn.

\section{Specific Objectives}

- Determine, according to the Farm Bill 2002, the subsidy contribution granted by the U.S. government to its farmers for these two products.

- Determine, for different scenarios, the effect of importing wheat and corn from the U.S. on the degree of competitiveness of Chilean producers.

\section{Materials and Methods}

The information used in carrying out this study comes mainly from two sources: 
- Background statistics obtained from the United Nations Organization for Food and Agriculture (FAOSTAT); from the United States Department of Agriculture (USDA); from the Oficina de Estudios y Políticas Agrarias (Office of Agricultural Research and Policy) (ODEPA) and from the Banco Central de Chile. In addition to these sources, information was compiled about cultivated surface areas, production volume, yields, prices and the trade balance between Chile and the U.S.

- Bibliographic information obtained from reviewing magazine articles, research and publications on the FAIR Act of 1996 and the Agricultural Farm Bill of 2002.

In order to prepare the technical data about crops, research and articles from the U.S. Department of Agriculture (USDA), Departmento de Economía Agraria de la Universidad de Talca (Agricultural Economics Department), the Instituto de Investigaciones Agropecuarias (INIA) (Agricultural Research Institute), and Fundación Chile.

From the American market prices for wheat and seed corn in the 2002-2003 season, subsidies granted by the American government to its farmers under Title 1 (referring to commodities) of the Farm Bill were determined.

This law establishes the following prices and payments as detailed below:

- Guaranteed Loan Rates.

- Compensatory Payments

- Fixed or Direct Payments

- Guaranteed Real Price, which corresponds to loan rates plus fixed payments

- Target price, which is the minimum amount farmers received per ton of produce.

- Counter-cyclical payments, which are activated when the income of the producers falls below the Target Price, which is determined for each crop.

Guaranteed loan rates and the target prices are fixed by the American government, while the fixed payments are determined based on the sown surface area and the yields obtained corresponding to the 1998 - 2001 period. The compensatory payments are paid out only when the 
market price falls below the guaranteed loan rates. The counter-cyclical payments are activated when the producers' income falls below the target price, that is, when the market price plus the fixed payment is inferior to the target price. In the case where the market price was less than the guaranteed loan rate, the counter-cyclical payment would correspond to the following equation:

\section{Counter-cyclical payments $=$ target price $-[$ fixed price + guaranteed loan rate)]}

All the prices and payments previously detailed were calculated in dollars per 100 kilograms (US\$/100 kg.).

The wheat and corn technical data for Chile, as well as the U.S., are found in the attached tables. For the latter country, a standard data card for both grains was considered, where the items for production factors and items are grouped together, but not so for farm labor. In addition, considering that the biggest and best producers in the U.S. receive a greater amount of subsidies, a high technological level for both countries was assumed. On the other hand, given the differences between the crop data cards for each country, a standard card was adapted for these which included all the items in the production process (see Table 4). The above-mentioned card allowed a more homogeneous comparison and analysis of the competitive position in which the Chilean producers for both crops find themselves.

According to Table 4, the production costs in the U.S. for both crops consider: seeds, fertilizers, pesticides. In addition, the item "Agricultural machinery expenses" includes diesel oil, oil and repairs; the item "Other Costs" includes water rights payments; the item "Labour" includes personal and contracted hours of work. The items "harvest and freight" were not included as direct production costs due to the following suppositions:

- The big agricultural producers in the U.S. have their own machinery and transport.

- Wheat farmers cultivate on average $30 \%$ of their total lands to this grain. That is why that percentage is associated with machinery depreciation as a direct production cost, allowing a more homogeneous comparison with Chilean producers that posses a high level of technology. 
- In the case of corn producers, $40 \%$ of the total cost of machinery depreciation was considered as a direct production cost, since these farmers dedicate, on average, this percentage of their total cultivation area to this cereal.

Table 4 - Technical Standard sheet for direct production costs in Chile and the U.S.

\begin{tabular}{|l|}
\hline ITEM \\
\hline Seeds \\
\hline Fertilizers \\
\hline Pesticides \\
\hline $\begin{array}{l}\text { Agricultural machinery } \\
\text { expenses }\end{array}$ \\
\hline Machinery depreciation \\
\hline Labour \\
\hline Harvest \\
\hline Freight \\
\hline Other expenses \\
\hline DIRECT COSTS \\
\hline
\end{tabular}

Source: Adapted from annex, 2003.

The production costs for wheat and seed corn in Chile, include seeds; fertilizers; pesticides (herbicides, fungicides and insecticides); for the item "Agricultural machinery costs", the cost of the payment for such services was considered (that is, machinery depreciation is not included); other costs (unexpected items which correspond to $5 \%$ of the total direct cost); labor, harvest costs (equivalent to the cost of the service of an automotive harvester) and finally, freight. For this last item the following suppositions are made:

- Wheat freight costs: $\$ 350$ pesos/100 kg (4.99 US\$/ton).

- Corn freight costs: $\$ 430$ pesos/100 kg (6.13 US\$/ton).

The technical data cards for both countries were valued in dollars per hectare (US\$/h.), using the average price of the dollar in July of 2003.

The Gross margin per hectare was also calculated using the following equation: 


\section{GROSS MARGIN = TOTAL INCOME - TOTAL DIRECT COSTS (US\$/h.) (US\$/h.) (US\$/h.)}

Where:

Total Income: yield (100 kg/h.) * Price (US\$/100 kg). Total Direct Costs: of direct costs specified in the Technical Standard sheet

In the case of the U.S., the payments made by the Government through the Farm Bill 2002 (Title I) were added, and those payments were added to the Gross Margin. Determining wheat and seed corn production costs for both Chile and the U.S. allowed making a comparison between the Gross Margin and Average Cost Variables for both countries.

To determine the import costs to Chile of wheat and corn coming from the U.S., the market prices of these products for the 2002-03 season, plus the freight, insurance and current tariffs were considered.

As well, the effect of importing wheat and corn from the U.S. on the national agricultural market was analyzed, which permitted us to measure the degree of competitiveness for the Chilean producers of these grains.

The latter was done through a sensitivity analysis with respect to the import cost (measured in US\$/100 kg) of wheat and corn, compared with the variable average cost for national producers. The sensitivity analysis in the case of corn was done considering two types of producers: those using their own fields for their productive process and those who do the process in rented fields, which currently represent a significant percentage of the total cultivated surface area.

The following scenarios were studied:

\begin{tabular}{|l|l|}
\hline Case 1 & $\begin{array}{l}\text { Without fixed payments, without counter-cyclical payments, without export } \\
\text { subsidy, with tariff }\end{array}$ \\
\hline Case 2 & $\begin{array}{l}\text { Without fixed payments, without counter-cyclical payments, without export } \\
\text { subsidy, without tariff }\end{array}$ \\
\hline Case 3 & $\begin{array}{l}\text { With fixed payments, with counter-cyclical payments, without export sub- } \\
\text { sidy, with tariff }\end{array}$ \\
\hline Case 4 & $\begin{array}{l}\text { With fixed payments, with counter-cyclical payments, without export sub- } \\
\text { sidy, without tariff }\end{array}$ \\
\hline Case 5 & $\begin{array}{l}\text { Without fixed payments, without counter-cyclical payments, with export } \\
\text { subsidy, with tariff }\end{array}$ \\
\hline
\end{tabular}




\begin{tabular}{|l|l|}
\hline Case 6 & $\begin{array}{l}\text { Without fixed payments, without counter-cyclical payments, with export } \\
\text { subsidy, without tariff }\end{array}$ \\
\hline Case 7 & $\begin{array}{l}\text { With fixed payments, without counter-cyclical payments, with export sub- } \\
\text { sidy, with tariff }\end{array}$ \\
\hline Case 8 & $\begin{array}{l}\text { With fixed payments, with counter-cyclical payments, with export subsidy, } \\
\text { with tariff }\end{array}$ \\
\hline Case 9 & $\begin{array}{l}\text { With fixed payments, with counter-cyclical payments, with export subsidy, } \\
\text { without tariff }\end{array}$ \\
\hline
\end{tabular}

The terms are defined as:

- Fixed Payment, determined by the Farm Bill 2002 for wheat and corn in the 2002/03 season.

- Counter-cyclical Payments (Title I, Farm Bill 2002).

- Export Subsidies: Amount assumed by the U.S. government, to finance part of the costs associated with the marketing of export goods among which freight and insurance costs are highlighted.

- Tariff: Tax which affects the importing of wheat and corn from the U.S.

\section{Results}

\section{Agricultural production subsidies in the United States}

The main peculiarity of the new Farm Bill is its counter-cyclical character establishing the target prices, this is, payments in direct relation to production levels. Until the year 2001, producers were receiving direct payments calculated according to the cultivated surface area in the middle of the 90's and the yields obtained in the decade of the 80's. The Farm Bill 2002 updates to the 1998 - 2002 period the surface areas on which the direct payments are based, and updates the yields to the same period for the counter-cyclical payments. Those farmers, who cultivated their fields more intensively from 1996 on, expecting their representatives to lobby Congress to increase the amounts of the subsidies to be paid, managed to increase their incomes coming from the payments based on the prior law. 


\section{Direct production subsidies for wheat.}

In Figure 5.3 the following subsidies for the period 2002-2003 are observed:

- Guaranteed loan rates

US $\$ 10.29 / 100 \mathrm{~kg}$

- Fixed payments

$1.91 / 100 \mathrm{~kg}$

- The sum of the guaranteed loan rates and the fixed payments corresponds to the guaranteed real price

- Target price

- The difference between the target price and the guaranteed real price corresponds to the maximum counter-cyclical payment

Figure 3 - Graph of payments for wheat during 2002-2003

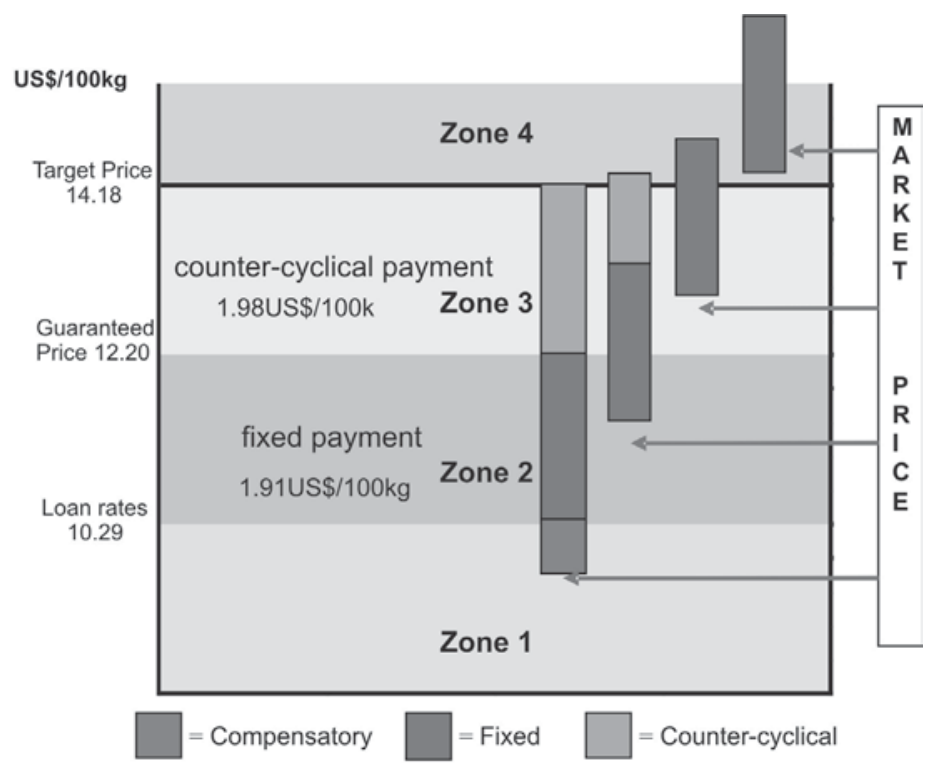

Source: created by the author from USDA data.

The counter-cyclical payments depend on the market price of wheat, which is not the case for fixed payments. If the market price falls lower than the guaranteed loan rate (zone 1 in Figure 3 ) there is a compensa- 
tory payment in order to reach the guaranteed loan rate, after which the fixed payment and the maximum counter-cyclical payment are made in order to arrive at the target price (US $\$ / 100 \mathrm{~kg}-14.18$ in the 200203 season). The agricultural law established a limit of US\$ 75,000 per farmer for the compensatory payments.

If the market price is located in zone 2, the fixed payments and the counter-cyclical payments (not maximum) are made in order to reach the target price.

When the market price is located in zone 3, the fixed payments are made and the counter-cyclical payments are activated only when the market price plus the fixed payment do not reach the target price. Finally, if the market price is greater than the target price (zone 4) the fixed payments are still made but the counter-cyclical payments are not.

Wheat production subsidies for the period 2004-2007 had an established guaranteed loan rate of $10.10 \mathrm{US} \$ / 100 \mathrm{~kg}$, a guaranteed real price of $12.01 \mathrm{US} \$ / 100 \mathrm{~kg}$ (the fixed payment was maintained at $1.99 \mathrm{US} \$ / 100$ $\mathrm{kg}$ ) and a target price of $14.40 \mathrm{US} \$ / 100 \mathrm{~kg}$, with which the maximum counter-cyclical payments arrived at 2.39 US\$/100 kg.

The price given to the producer by the USDA in July of 2003 was $12.19 \mathrm{US} \$ / 100 \mathrm{~kg}$. If the target price was fixed at $14.18 \mathrm{US} \$ / 100 \mathrm{~kg}$, the difference (1.99 US $\$ / 100 \mathrm{~kg}$ ) would be contributed by the Farm Bill (1.91US\$/100 kg by fixed payment and $0.08 \mathrm{US} \$ / 100 \mathrm{~kg}$ by counter-cyclical payments).

Production for the 2002/03 season was estimated at 51.32 million tons, where each ton would cost the American government US $\$ 19.90$ in direct subsidies, which means that the annual contribution to wheat farmers via the Commodities Program of the Farm Bill 2002 would be slightly over 1.021 billion dollars. Since the surface area sown with wheat in the 2002/03 season was 18,542,000 hectares involving an average yield of $2,800 \mathrm{~kg} / \mathrm{h}$., each hectare should receive a payment of US $\$ 55.06$. If we consider the yields $(3,500 \mathrm{~kg} / \mathrm{h}$.) obtained by farmers possessing a high level of technology, these farmers would receive US\$ 69.65 per hectare by way of direct subsidies. 


\section{Direct production subsidies for corn}

Just the same as for wheat, there are two periods where the subsidies granted by the U.S. government to corn producers vary. For the period 2002-2003, the following values were established for subsidies:

- Guaranteed loan rate

- Fixed payment

- Guaranteed real price (GLR + FP)

- Target price

- Maximum counter-cyclical payment
$7.80 \mathrm{US} \$ / 100 \mathrm{~kg}$

$1.10 \mathrm{US} \$ / 100 \mathrm{~kg}$

$8.90 \mathrm{US} \$ / 100 \mathrm{~kg}$

$10.24 \mathrm{US} \$ / 100 \mathrm{~kg}$

1.34 US $\$ / 100 \mathrm{~kg}$

In the same manner as shown in Figure 5.3, if the market price for corn corresponds to Zone 1 (below the guaranteed loan rate), the compensatory payments are activated, then the fixed payments and the maximum counter-cyclical payments until reaching the target price of $10.24 \mathrm{US} \$ / 100 \mathrm{~kg}$ for the $2002 / 03$ season. When the market price is in Zone 2, the fixed payments and the counter-cyclical payments (not maximum) are made in order to arrive at the target price. If the market price is located in Zone 3, the fixed payments and the counter-cyclical payments come into effect only if the market price plus the fixed payments do not reach the target price. If the market price exceeds the target price (Zone 4) only the fixed payments are made.

For the period 2004-2007 a guaranteed loan rate was fixed at 7.68 US $\$ / 100$ $\mathrm{kg}$; the guaranteed real price was $8.78 \mathrm{US} \$ / 100 \mathrm{~kg}$ (the fixed payment was maintained at $1.10 \mathrm{US} \$ / 100 \mathrm{~kg}$ ); the maximum counter-cyclical payment was established at $1.57 \mathrm{US} \$ / 100 \mathrm{~kg}$; and finally, the target price reached 10.35 US\$/100 kg, 0.11 US\$/100 kg more than the 2002-2003 period.

The price of corn granted to the producer by the USDA in July of 2003 was 8.65 US $\$ / 100 \mathrm{~kg}$. If the target price was fixed at $10.24 \mathrm{US} \$ / 100$ $\mathrm{kg}$, the difference (1.59 US $\$ / 100 \mathrm{~kg}$ ) would be contributed by the Farm Bill (1.10 US\$/100 kg by fixed payment and 0.49 US $\$ / 100 \mathrm{~kg}$ via the counter-cyclical payments).

The production for the 2002/03 season was estimated at 225.54 million tons therefore each ton would cost the U.S. government US\$ 15.90 in direct subsidies which means that the annual contribution through the commodities program of the Farm Bill 2002 would be 3.586 billion dollars for corn. Since the surface area sown with corn in the 2002/03 season was 
$28,050,000$ hectares involving an average yield of $8,040 \mathrm{~kg} / \mathrm{h}$., each hectare should receive a payment of US $\$ 127.83$. Considering the yields $(9,000$ $\mathrm{kg} / \mathrm{h}$.) obtained by farmers possessing a high level of technology, these farmers would receive US $\$ 143.10$ per hectare by way of direct subsidies.

\section{Analysis of the competitiveness of Chilean corn and wheat producers. Comparison of direct production costs between Chilean and American wheat and corn growers}

Table 5 - Direct production costs and Gross Margin for wheat and corn in Chile and the U.S. (US\$/h.)

\begin{tabular}{|l|c|c|c|c|c|}
\hline \multirow{2}{*}{ ITEM } & \multicolumn{2}{|c|}{ WHEAT } & \multicolumn{3}{c|}{ CORN } \\
\cline { 2 - 6 } & Chile & EE.UU. & $\begin{array}{c}\text { Chile } \\
\text { (no RL) }\end{array}$ & $\begin{array}{c}\text { Chile } \\
\text { (with RL) }\end{array}$ & U.S. \\
\hline Seeds & 50.49 & 17 & 168.15 & 168.15 & 85.13 \\
\hline Fertilizers & 141.57 & 59.13 & 224.62 & 224.62 & 117.67 \\
\hline Pesticides & 93.20 & 18.11 & 41.04 & 41.04 & 71.96 \\
\hline Agricultural machinery expenses & 108.11 & 48.50 & 195.40 & 195.40 & 120.21 \\
\hline Machinery depreciation & - & 37.13 & - & - & 73.55 \\
\hline Rent of Land & - & - & - & 213.94 & - \\
\hline Labour & 60.97 & 62.71 & 170.44 & 170.44 & 121.72 \\
\hline Harvest & 35.27 & - & 64.18 & 64.18 & - \\
\hline Freight & 32.45 & - & 95.06 & 95.06 & - \\
\hline Other expenses & 26.11 & 1.53 & 47.94 & 58.64 & 0.79 \\
\hline TOTAL DIRECT COSTS & 548.17 & 244.11 & $1,006.83$ & $1,231.47$ & 591.03 \\
\hline Yield (100kg/ha) & 65 & 35 & 155 & 155 & 90 \\
\hline Average costs (US\$/100kg) & 8.43 & 6.97 & 6.50 & 7.94 & 6.56 \\
\hline $\begin{array}{l}\text { Market price (US\$/100kg) } \\
\text { in July of 2003 }\end{array}$ & 17.68 & 12.19 & 11.41 & 11.41 & 8.65 \\
\hline GROSS INCOME & $1,149.2$ & 426.65 & 1,769 & 1,769 & 778.50 \\
\hline GROSS MARGIN & 601.03 & 182.54 & 761.72 & 537.53 & 187.47 \\
\hline SUBSIDY* & - & 69.65 & - & & 143.10 \\
\hline GROSS MARGIN + SUBSIDY & 601.03 & 252.19 & 761.72 & 537.53 & 330.57 \\
\hline
\end{tabular}

No RL = without rent of land; with RL = with rent of land.

* Subsidy corresponding to Title I of the Farm Bill 2002.

Source: created by the author, 2003. US $\$$ in July of $2003=\$ 701.14$ Chilean pesos 
With respect to wheat, Table 5 presents a comparison of the direct costs of production in Chile and the U.S. for the year 2003. As well, this Table shows the gross margins (US\$/h.) for yields produced with a high level of technology, that is, $6,500 \mathrm{~kg} / \mathrm{h}$. for Chile and 3,500 kg/h. for the U.S. The prices used in this analysis (July 2003) were 17.68US\$/ $100 \mathrm{~kg}$ in the case of Chile (ODEPA, 2003) and 12.19 US $\$ / 100 \mathrm{~kg}$ for the U.S.(price estimated by the USDA). This table also shows the subsidies granted to American farmers via the Farm Bill 2002 whose amount corresponds to the difference between the market price $(12.19 \mathrm{US} \$ / 100 \mathrm{~kg})$ and the target price-2003 (14.18US\$/100 kg); that is $1.99 \mathrm{US} \$ / 100 \mathrm{~kg}$. Said amount multiplied by the quantity of grain produced gives rise to a subsidy of US $\$ 69.65 /$ hectare. Variable average costs (US\$/100 kg) were lower in the U.S., however the great difference in yield and price per hundredweight, resulted in Chile's gross margin being 138\% greater. This percentage would increase to $229 \%$ if the government of the U.S. did not directly subsidize the production of agricultural goods.

In Chile, the direct production costs for corn reached US\$1,006.83 / h., (US $\$ 415.80 / \mathrm{h}$. more than in the U.S.). However, the variable average costs are slightly lower in Chile mainly due to its yield levels $(15,500 \mathrm{~kg} /$ h. versus $9,000 \mathrm{~kg} / \mathrm{h}$. in the U.S.).

Direct subsidies for the production of corn in the U.S. correspond - as do those for wheat - to the difference between the market price (8.65US\$/100kg) and the target price-2003 (10.24US\$/100 kg), that is 1.59 US $\$ / 100 \mathrm{~kg}$. Said amount multiplied by the yield $(9,000 \mathrm{~kg} / \mathrm{h}$.) gives us a total subsidy of US\$143,10/h.

The differences between gross margins, without considering subsidies, are greater in Chile by US $\$ 574.25 / \mathrm{h}$. than in the U.S. Upon inclusion of the subsidies, the difference between gross margins lowers to US $\$ 431.10 / \mathrm{h}$. In other words, through subsidies alone, the corn producers in the U.S. increase their gross margin by $76.33 \%$, reflecting the great influence that subsidies have on agricultural production, which in this case corresponds only to Title 1 of the Farm Bill 2002.

In Chile, when the rent of land is included in the direct production costs, they increase to US $\$ 1,231.47$ per hectare; therefore the variable average costs also increase. The gross margin is US\$ 537.53 per hectare, that is, $29 \%$ less than that of the producers who do not rent land. 
Nevertheless, considering the market prices of 2003, this gross margin remains competitive compared to that obtained by American producers (330.57 US\$/h.).

In this scenario, the Chilean producers' gross margin exceeds by US $\$ 206.96 / \mathrm{h}$. that obtained by their American counterparts even with the subsidies that they receive. Without taking into consideration the item "rent of land", the difference in these gross margins is US $\$ 270.46 /$ h., $52 \%$ greater.

For both wheat and corn production the differences in the use of agricultural products for production of these grains in the two countries call our attention:

- Seeds: Chilean producers use a significantly greater amount of seeds than the U.S. producers, which is reflected in the density of plants per hectare permitting higher yields.

- Fertilizers: For both crops, a great difference in the use of these products is shown. It could be thought of as excessive fertilization in Chile; however the difference clearly points out the strength/density of the crops. While in Chile there is a very intensive crop growing, the producer in the U.S. opts for much more extensive crops corresponding to the size of the properties and the availability of labour. The quantity of fertilizer used is also evident in the crop yields in each country.

- Agricultural chemical products: In the case of wheat, the use of a greater quantity of these products is observed in Chile mainly due to continuously planting the same crop (one-crop systems), of which the consequence is an increase in plant diseases. In the case of corn, the U.S. shows a higher level of use of agricultural chemicals, nevertheless they are considered within the normal range and, as in Chile, a reasonable use is made of them.

\section{Wheat Producers}

The difference between the FOB and CIF prices in 2003 was 17.50 US\$/ton. It can be assumed that this difference corresponds to marketing costs, especially maritime freight plus the cost of insurance. However, the values given by the Compañía Sudamericana de Vapores (CSAV) indicate that the cost of transporting grain from the east coast of the 
U.S. to the port of San Antonio, Chile was US\$1,575 per container (40foot, maximum weight of 26.681 tons); that is, 59.03 US\$/ton. Consequently it is assumed that there would be an export subsidy that would cover $70.33 \%$ of the costs associated with exporting goods (freight and insurance, $\mathrm{f}+\mathrm{i}$ ) between the U.S. and Chile.

The tariff on wheat coming into our country from the U. S. corresponds to an $8 \%$ ad valorem the sum of which should be adjusted to the price list in force. On average, up to August 2003, the CIF value of a ton of wheat coming from the U.S. reached US\$148.52. If we add the $8 \%$ tariff to this amount, we arrive at a total of $160.40 \mathrm{US} \$ /$ ton, a value very close to the floor of the list in force for wheat (161 US\$/ton).

The following sensitivity analysis makes reference to the cost of importing $100 \mathrm{~kg}$ of wheat from the U.S. according to the various scenarios mentioned in the methods section. These values are compared with the cost of producing $100 \mathrm{~kg}$ in Chile (AVC, Average Variable Cost) for producers with a high level of technology, that is, those who produce $6,500 \mathrm{~kg} / \mathrm{h}$. and whose direct production costs are $548.17 \mathrm{US} \$ / \mathrm{h}$. $($ AVC $=8.43 \mathrm{US} \$ / 100 \mathrm{~kg})$. The fixed payments and the counter-cyclical payments correspond to direct production subsidies for agriculture in the U.S. The fixed payment was $1.91 \mathrm{US} \$ / 100 \mathrm{~kg}$, while the counter-cyclical payment corresponds to the difference between the target price - 14.18 US $\$ / 100 \mathrm{~kg}$ in the 2002/03 season - and the market price (12.19 US $\$ / 100 \mathrm{~kg}$ ) plus the fixed payment. That is to say, CCP $=$ TP - (market price $+\mathrm{FP}$ ). According to this formula, the counter-cyclical payment was $0.08 \mathrm{US} \$ / 100 \mathrm{~kg}$.

In the scenarios where the fixed payments and the counter-cyclical payments are included, these will be discounted from the direct production costs and will be seen reflected in a decrease in the AVC (Figure 4). As previously mentioned, the subsidy associated with marketing export products plus the cost of insurance covers $70.33 \%$ of the freight costs. In the cases which include an export subsidy, the cost of freight and insurance will be $1.75 \mathrm{US} \$ / 100 \mathrm{~kg}$, while in the cases where there is no export subsidy, these costs will be $5.90 \mathrm{US} \$ / 100 \mathrm{~kg}$. The ad valorem tariff of $8 \%$ represents an additional cost of $1.19 \mathrm{US} \$ / 100 \mathrm{~kg}$ and it is calculated using the average CIF value (August 2003) for a ton of wheat coming from the U.S. (148.52 US\$/ton). 
Figure 4 - Cost of importing $100 \mathrm{~kg}$ of wheat from the U.S.

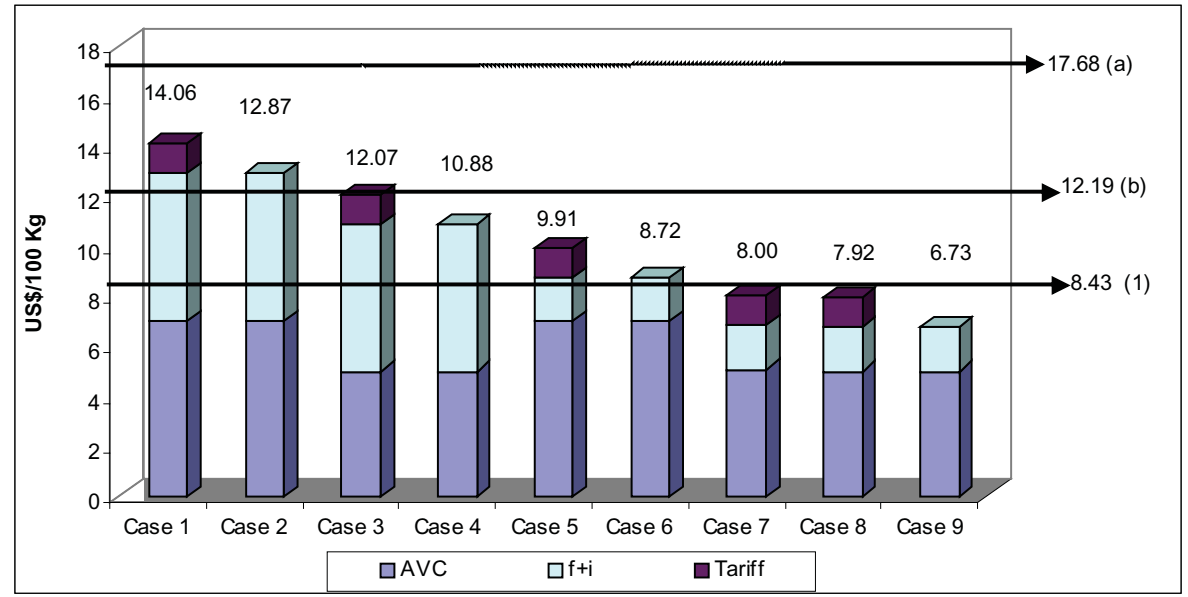

1. Corresponds to AVC of Chilean wheat producers ( $8.43 \mathrm{US} \$ / 100 \mathrm{~kg}$ ).

a. Price for Chilean producers, July 2003 (17.68 US\$/100 kg).

b. Price for American producers, July 2003 (12.19 US $\$ 100 \mathrm{~kg})$.

Source: created by the author, with information by ODEPA, USDA 2003.

Case 1 of Figure 4 shows a favourable scenario for the national producers who possess an AVC of $8.43 \mathrm{US} \$ / 100 \mathrm{~kg}$, given that the cost of importing one $100 \mathrm{~kg}$ of wheat from the U.S. is $14.06 \mathrm{US} \$ / 100 \mathrm{~kg}$ without considering subsidies and including the tariff. The American export subsidy greatly affects the lowering of import costs per $100 \mathrm{~kg}$ of wheat if we compare the costs where an export subsidy is granted to those where only the direct production subsidy is applied (case 6 versus case 4).

Currently the import cost per $100 \mathrm{~kg}$ of wheat coming from the U.S. is US\$ 7.92 (case 8), an amount which leaves the national producers unable to compete. To obtain the AVC they would have to increase their yields from 6,500 to $6,852 \mathrm{~kg} / \mathrm{h}$. or else, reduce their direct production costs by $5.3 \%$. Case 9 graphs a situation that includes the opening of the wheat market facing subsidized agriculture where the import cost per $100 \mathrm{~kg}$ of wheat is US\$6.73. In this case, in order to maintain their competitiveness the Chilean producers would have to obtain a yield over $8,000 \mathrm{~kg}$ per hectare (obtaining an AVC of $6.73 \mathrm{US} \$ / 100 \mathrm{~kg}$ ) or, reduce their direct costs by $20.19 \%$. 


\section{Corn producers}

The difference between the CIF and Fob prices in 2002 reached 9.09 US\$/ton. For the year 2003, the CIF price (without tariff) for one ton of grain coming from the U.S. was estimated at $124 \mathrm{US} \$ /$ ton, while the Golfo FOB value was 109.10 US\$/ton, making a difference of 14.90 US\$/ ton. As previously mentioned, the cost of freight plus insurance between the U.S. and Chile was 59.03 US\$/ton, estimating a $74.75 \%$ subsidy for freight and insurance ( $f+i)$ from the U.S. government. Hence the explanation of why grains sent from the U.S. arrive in our country at price ranges that are competitive with, or even inferior to, the price of grain from other countries that have lower freight costs such as Argentina.

The tariff on corn shipments from the U.S. corresponds to $8 \%$ ad valorem. With the coming into force of the FTA, an immediate tariff reduction would take place. If the tariff is discounted from the entry price of corn (134.06 US\$/ton in July 2003) imported from the U.S., it would fall to 124 US\$/ton, which would be lower than the current price of corn imported from Argentina (128.36 US\$/ton).

The following sensitivity analysis makes reference to the import cost per $100 \mathrm{~kg}$ of corn from the U.S. assuming the same scenarios that were used for the wheat analysis. These values are compared with the cost of producing $100 \mathrm{~kg}$ of corn in Chile (AVC) for producers with a high level of technology, producing $15,500 \mathrm{~kg} / \mathrm{h}$. and whose direct production costs are 1,006.83 US $\$ / \mathrm{h}$., that is with an AVC of $6.50 \mathrm{US} \$ / 100 \mathrm{~kg}$.

The fixed payments and the counter-cyclical payments correspond to direct agricultural subsidies for corn production in the U.S., with the fixed payment being $1.10 \mathrm{US} \$ / 100 \mathrm{~kg}$ while the counter-cyclical payment corresponds to the difference between the target price - which was $10.24 \mathrm{US} \$ / 100 \mathrm{~kg}$ in the $2002 / 03$ season- and the market price (8.65 US\$ $/ 100 \mathrm{~kg}$ ) plus the fixed payment, arriving at a counter-cyclical payment of 0.49 US $\$ / 100 \mathrm{~kg}$.

In cases where fixed payments and counter-cyclical payments are included, these will be deducted from the direct production costs and will be seen reflected in a decrease in the AVC (see Figure 5). The export subsidy covers $74.75 \%$ of the costs associated with trading this product (freight and insurance, $f+i$ ). Thus, in cases where the export subsidy is included 
the cost of freight and insurance will be $1.49 \mathrm{US} \$ / 100 \mathrm{~kg}$, while in the cases not including the export subsidy, the cost will be $5.90 \mathrm{US} \$ / 100 \mathrm{~kg}$.

The $8 \%$ ad valorem tariff represents an additional cost of 0.99 US $\$ / 100$ $\mathrm{kg}$ and is calculated on the estimated CIF value in January - August of 2003 for one ton of corn coming from the U.S. (124.00 US\$/ton).

As in the nine cases previously analyzed, Figure 5 graphs the different import costs for $100 \mathrm{~kg}$ of corn coming from the U.S. in terms of AVC, freight + insurance, and tariffs. In Case 1, a scenario where there are tariffs but no subsidies, the cost of importing corn is 13.45 US\$/ 100 $\mathrm{kg}$, which is a very favouable for national corn producers possessing an AVC of 6.50 US $\$ / 100 \mathrm{~kg}$. Just as for wheat, the export subsidy has a greater percentage of influence on the import value than the direct product subsidy has. That is to say that the export subsidy on $100 \mathrm{~kg}$ of corn coming from the U.S. is more detrimental to national producers than the second subsidy mentioned (Case 6 versus Case 4).

Figure 5 - Cost of importing $100 \mathrm{~kg}$ of corn from the United States

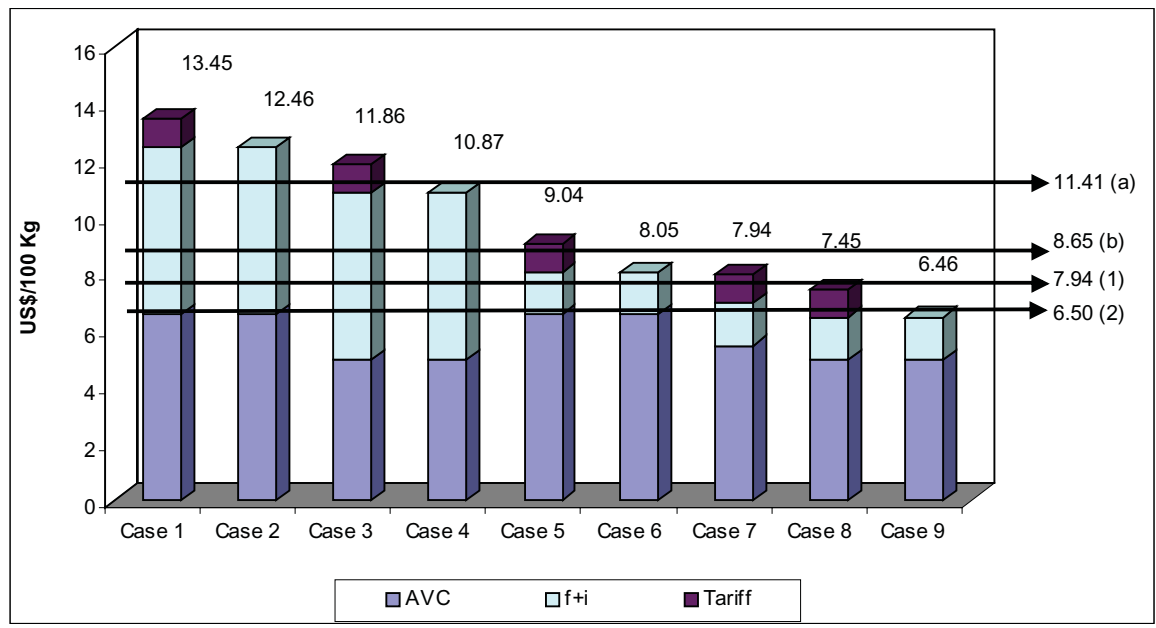

1. Corresponds to the AVC of Chilean corn producers including land rent $(7.94 U S \$ / 100 \mathrm{~kg})$

2. Corresponds to the AVC of Chilean corn producers $(6.50 \mathrm{US} \$ / 100 \mathrm{~kg})$.

a. price for the Chilean producer, July 2003 (11.41 US\$/100 kg).

b. price for the American producer, July 2003 (8.65 US\$/100 kg).

Source: created by the author, with information by ODEPA, USDA 2003. 
For the year 2003, the cost of corn coming from the U.S. was 7.45 US\$/100 kg (Case 8), which allowed national corn producers to still be competitive.

Case 9 graphs a scenario where corn is imported from the U.S. with the corresponding subsidies granted by the U.S. but without tariffs. Here, the cost of importing corn is 6.46 US\$/100 kg, a value lower than the AVC of national producers. This case makes clear the effect of the current tariff on corn imported from the U.S. (8\% ad valorem).

It must be noted that with the coming into force of the FTA, this product will have an immediate tariff reduction, a situation as presented in Case 9. In this scenario, producers find themselves in a rather unfavourable position for maintaining adequate competitiveness (measured by the AVC, they will have to produce a minimum of $15,585 \mathrm{~kg} / \mathrm{h}$.).

For Chilean producers who rent land, which today is a very common practice involving a large surface area of corn (Departamento de Economía Agraria, 2001), the AVC increases from 6.50 to 7.94 US $\$ / 100$ $\mathrm{kg}$. In this case, so that these farmers can maintain their competitiveness, they would have to produce $19,000 \mathrm{~kg} / \mathrm{h}$. or else reduce their production costs by $18.7 \%$.

After having done this analysis, we can firmly state that with respect to shipments from the U.S. the loss of competitiveness for the corn producers in our country (whether they rent the land or not) is due to the large quantity of subsidies involved. Seen in this manner, one form of confronting this type of distortion existing in international trade would be to apply tariffs. However, as previously mentioned, these tariffs will be eliminated.

\section{Conclusions}

With respect to the American Food Security and Rural Investment Act or Farm Bill 2002 (Title 1), the following can be concluded:

- In the 2002/2003 season each hectare of wheat received an average of US\$55.06. The farmers with a high level of technology $(3,500 \mathrm{~kg} / \mathrm{h}$.) would have received through direct subsidies $69.65 \mathrm{US} \$ / \mathrm{h}$. In the case of the corn producers, each hectare received, on average, a payment of US\$127.83 and farmers with a high level of technology $(9,000 \mathrm{~kg} / \mathrm{h}$. 
yield) would have received a subsidy of $143.10 \mathrm{US} \$ / \mathrm{h}$. It's mean that the U.S. the direct subsidies increase the gross margin of the wheat and corn producers by $30.64 \%$ and $76.33 \%$, respectively.

With respect to the comparison between Chilean and American direct production costs and gross margin for wheat and corn, the following could be concluded:

- The direct costs of wheat production in Chile are greater than those of the U.S. by $127.7 \%$ (548.17 US\$/h. versus $244.11 \mathrm{US} \$ / \mathrm{h}$.) On the other hand, the wheat yields in Chile reached $6,500 \mathrm{~kg} / \mathrm{h}$. exceeding those of the U.S. by $116.6 \%(3,500 \mathrm{~kg} / \mathrm{h}$.), considering similar technological conditions.

- The gross margin for national wheat supersedes that of the U.S. by $229 \%$, but when the direct production subsidies to American farmers are included, the difference diminishes to $138 \%$. The direct subsidies granted by the U.S. to its farmers enable them to increase the gross margin by $38.16 \%$, considering the aforementioned production rate.

- With reference to corn, the total direct costs in Chile are 1,006.83 US\$/h., while in the U.S. they reach 591.03 US $\$ /$ h. However, the yield from farmers with a high level of technology is $15,500 \mathrm{~kg} / \mathrm{h}$. and those of the U.S. only reach $9,000 \mathrm{~kg} / \mathrm{h}$.

- The gross margin for corn in the U.S. is $330.57 \mathrm{US} \$ / \mathrm{h}$. including direct subsidies, whereas that of the Chilean producers is 761.72 US\$/ h. By eliminating the direct subsidies for corn production in the U.S., the gross margin for Chilean producers exceeds that of their U.S. counterparts by $306.09 \%$. Considering the previously indicated production rate, the American farmers obtain 187.47 US $\$ / \mathrm{h}$. in direct subsidies, which increase their gross margin by $76.33 \%$.

- By including land rent in the direct production costs for Chilean corn producers, the gross margin decreases by $29 \%$. The difference in gross margin compared with that of the U.S. decreases from 431.15 to $206.96 \mathrm{US} \$ / \mathrm{h}$.

With respect to the competitiveness of national wheat and corn producers the following is concluded:

- The cost of importing wheat from the U.S. with a $0 \%$ tariff, export subsidies and direct production subsidies is $6.73 \mathrm{US} \$ / 100 \mathrm{~kg}$, a value less than the AVC (8.43 US $\$ / 100 \mathrm{~kg}$ ) incurred by the Chilean producers with a high level of technology. 
- The cost of importing corn from the U.S. with a $0 \%$ tariff, export subsidies and direct production subsidies is $6.46 \mathrm{US} \$ / 100 \mathrm{~kg}$, a value very similar to the AVC (6.50 US $\$ / 100 \mathrm{~kg}$ ) incurred by the Chilean producers with a high level of technology. However, in order to achieve this level of AVC, it is necessary to obtain yields superior to $15,500 \mathrm{~kg} / \mathrm{h}$.

With respect to the grain trade between Chile and U.S. the following can be concluded:

- Both Corn and Wheat production in Chile does not have influence on the international trade and world-wide prices, because Chile is an import country of these goods, and its internal prices of market are based on international prices. If the prices of grains drop given by a gradual diminish in the applied tariffs, then the viable option for these producers -to medium and long term- is the to change his production to other agricultural goods such as fresh fruits or other raw materials for food industries. These kinds of goods have real opportunities of international trade due to the commercial agreements that Chile has signed in the last years.

- In Chile, habitually the wheat producers do not rent land; only the corn producers do it, because this type of producers has lower land. Therefore, if the price of corn is high, then the corn producer makes the decision to rent land. On the other hand, if the price is low these growers would not rent land, as answer to a probable diminution of the yield of corn. That is to say, the opportunity cost of land is a short term decision, based on the corn price of the previous season.

\section{References}

ACTIONAID. 2002. Rentabilidad en la agricultura. Available in http://www. actionaid.org. [20 March, 2003].

BANCO CENTRAL DE CHILE, 2003. Bases de datos económicos, Indicadores del día. Available in http://www.bcentral/basedatoseconómicos. [6 August, 2003]

BASCO, C; BUCCELLATO, I; DELICH, V; TUSSIE, D. 2002. La nueva Farm Bill. Ley de seguridad agrícola e inversión rural de los Estados Unidos.. Available in http://www.latn.org.ar/articles/farm bill_2002.htm. [4 May, 2003]. 
DEPARTAMENTO DE ECONOMÍA AGRARIA. 2001. Economía Agraria de la producción de maíz en la VI región. Universidad de Talca. 117 p.

DIRECCIÓN DE PROMOCIÓN DE EXPORTACIONES (ProChile). 1995. New York. 39 p.

EL MERCURIO. Insumos agropecuarios. En: Revista del campo. No 1.408 . Cuerpo B, p.5. [7 July, 2003].

INSTITUTO NACIONAL DE ESTADÍSTICA (INE), 2003. Estadísticas Agropecuarias. Available in http://www.ine.cl [20 September, 2003].

METHOL, M. 2002. Nueva Ley agrícola de Estados Unidos: algunos aspectos destacados. ODYPA-ANUARIO. 5p.

MITTOL, A. 2002. Perdiendo nuestra tierra: La Ley Agrícola del 2002. Food First Institute for food and development. Policy, USA. Available in http:// www.foodfirst.org/pubs/backgrdrs/2002/leyagrícola.html. [16 March, 2003].

OFICINA DE ESTUDIOS Y POLÍTICAS AGRARIAS (ODEPA). 2001. Condiciones de ingreso para los productos silvoagropecuarios importados por Chile. Available in http://www.odepa.cl. [21 May, 2003].

OFICINA DE ESTUDIOS Y POLÍTICAS AGRARIAS (ODEPA), 2002. Situación del mercado del maíz. Ministerio de Agricultura, Gobierno de Chile. Available in http://www.odepa.cl. [14 March, 2003].

OFICINA DE ESTUDIOS Y POLÍTICAS AGRARIAS (ODEPA), 2002. Mercado del trigo. Ministerio de Agricultura, Gobierno de Chile. Available in http://www.odepa.cl. [23 April, 2003].

OFICINA DE ESTUDIOS Y POLÍTICAS AGRARIAS (ODEPA). 2003. El tratado de libre comercio entre Chile y EE.UU. Available in http://www.odepa.cl. [5 March, 2003].

OFICINA DE ESTUDIOS Y POLÍTICAS AGRARIAS (ODEPA), 2003. El mercado del maíz. Ministerio de Agricultura, Gobierno de Chile. Available in http://www.odepa.cl. [2 August, 2003].

OFICINA DE ESTUDIOS Y POLÍTICAS AGRARIAS (ODEPA), 2003. Precios de Insumos y productos agropecuarios. Ministerio de Agricultura, Gobierno de Chile. Available in http://www.odepa.cl. [15 July, 2003]. 
OFICINA DE ESTUDIOS Y POLÍTICAS AGRARIAS (ODEPA), 2003. Precios mayoristas: trigo y maíz. Precios reales sin IVA con IPC de 07/2003. Ministerio de Agricultura, Gobierno de Chile. Available in http://www.odepa. cl. [15 de August, 2003].

OFICINA DE ESTUDIOS Y POLÍTICAS AGRARIAS (ODEPA), 2003. Precios Internacionales: trigo y maíz, nominales sin IVA. Ministerio de Agricultura, Gobierno de Chile. Available in http://www.odepa.cl. [15 de August, 2003].

ORGANIZACIÓN MUNDIAL DE COMERCIO (OMC). 2000. El Comercio Mundial en el año 2000. Visión general. Available in http://www.wto.org/ spanish/res_s/statis_s/its.2001_s/chp-1.pdf. [2 June, 2003].

SILVA, C. 2003. Notas acerca del Tratado de Libre Comercio entre Chile y Estados Unidos. Santiago de Chile. 21 p.

UNITED STATED DEPARTMENT OF AGRICULTURE (USDA). 2001. Characteristics and Production Costs of U.S. Corn Farms. Electronic Report from the ERS. Available in http://www.ers.usda.gov. [23 June, 2003].

UNITED STATED DEPARTMENT OF AGRICULTURE (USDA). 2002. Direct payments for wheat, feed grains. Available in http://www.ers.usda.gov/ Features/FarmBill/analysis/directpayments2002act.htm.[8 May, 2003].

UNITED STATED DEPARTMENT OF AGRICULTURE (USDA). 2002. Farm Characteristics, Farm Financial Indicators. Economic Research Service, USDA, Washington DC. 2002. Available in http://www.ers.usda.gov. [20 August, 2003].

UNITED STATED DEPARTMENT OF AGRICULTURE (USDA), 2003. World Agricultural Supply And Demand Estimates (WASDE-96). Available in http://www.usda.gov. [13 May, 2003].

UNITED STATED DEPARTMENT OF AGRICULTURE (USDA), 2003. World Agricultural Supply And Demand Estimates (WASDE-401). Available in http:/www.usda.gov/oce/waob/wasde/latest. [28 August, 2003].

VELASCO, R; GONZÁLEZ, J; CRUZ, J. 1996. Costos directos de producción de cultivos VII y VIII región, Instituto de Investigaciones Agropecuarias (INIA), Centro Regional de Investigación Quilamapu, Ministerio de Agricultura. Boletín $\mathrm{N}^{\circ} 71.254 \mathrm{p}$. 


\section{Annex}

Costs of Production: Corn-Chile ${ }^{1 \mathrm{~A}}$

\begin{tabular}{|l|c|c|}
\multicolumn{3}{|c|}{ Costs of Production: Corn-Chile ${ }^{\mathrm{A}}$} \\
\hline & $\begin{array}{c}\text { Chilean } \\
(\$) / \mathrm{h} .\end{array}$ & US $\$ / \mathrm{h}$. \\
\hline 1. Factor: Labour & & \\
Harrow & 3,000 & 4.28 \\
Urea & 5,000 & 7.13 \\
Herbicides & 3,000 & 4.28 \\
Sowing, Fertilizers & 6,000 & 8.56 \\
+ pesticides & 2,500 & 3.57 \\
Contour-furrow irrigation & 30,000 & 42.79 \\
Thinning and to earth & 25,000 & 35.66 \\
To weed manually & 45,000 & 64.18 \\
Irrigations & 119,500 & 170.44 \\
\hline Sub - Total & & \\
\hline 2. Factor: Machinery & 52,000 & 74.16 \\
Front power lift plough & 30,000 & 42.79 \\
Chisel plough & 8,000 & 11.41 \\
Fertilizer distributor & 16,000 & 22.82 \\
Fumigator & 20,000 & 28.52 \\
Corn drill & 45,000 & 64.18 \\
Reaper & 171,000 & 243.89 \\
\hline Sub - Total & & \\
\hline 3. Factor: Animal Labour & 11,000 & 15.69 \\
\hline Sub - Total & 11,000 & 15.69 \\
\hline 4. Factor: Means & & \\
Seed & 117,900 & 168.15 \\
Urea & 98,400 & 140.34 \\
Phosphate Fertilizer & 40,250 & 57.41 \\
Potash Fertilizer & 18,840 & 26.87 \\
Lorsban & 12,624 & 18 \\
Atrazine & 6,840 & 9.76 \\
MCPA & 9,308 & 13.28 \\
\hline Sub - Total & 304,162 & 433.81 \\
\hline Freight & & 95.06 \\
Unexpected items (5\%) & 47.94 \\
\hline Total Direct Costs & & $1,006.83$ \\
\hline
\end{tabular}


Costs de Production: Wheat -Chile ${ }^{A}$

\begin{tabular}{|l|r|r|}
\hline & $\begin{array}{r}\text { Chilean } \\
(\$) / h .\end{array}$ & \multicolumn{1}{|c|}{ US $\$$ h. } \\
\hline 1. Factor: Labour & & \\
Harrow & 2,700 & 3.85 \\
Urea & 2,700 & 3.85 \\
Herbicides & 4,500 & 6.42 \\
Sowing, Fertilizers + & 4,500 & 6.42 \\
pesticides & 1,350 & 1.93 \\
To clean & 6,750 & 9.63 \\
Contour-furrow irrigation & 4,500 & 6.42 \\
Fungicides & 15,750 & 22.46 \\
Irrigations & 42,750 & 60.97 \\
\hline Sub - Total & & \\
\hline 2. Factor: Machinery & 7,055 & 10.06 \\
Farm cart & 13,046 & 18.61 \\
Plough & 6,855 & 9.78 \\
Mouldboard plough & 3,129 & 4.46 \\
Ditching plough & 7,000 & 9.98 \\
Fertilizer distributor & 18,854 & 26.89 \\
Fumigator & 19,864 & 28.33 \\
Drilling machine & 24,732 & 35.27 \\
Reaper & 100,569 & 129.15 \\
\hline Sub - Total & 384,379 & 548.17 \\
\hline 3. Factor: Means & 35,400 & 50.49 \\
Seed & 57,400 & 81.87 \\
Urea & 41,860 & 59.7 \\
Phosphate fertilizer & 6,287 & 8.97 \\
Vincit Flo & 9,346 & 13.33 \\
Banvel 480 SL & 31,500 & 44.93 \\
Iloxan 28 EC & 2,058 & 2.93 \\
MCPA 750 & 16,156 & 23.04 \\
Bayleton 25\% WP & 200,006 & 285.26 \\
\hline Sub - Total & 32.750 & 32.45 \\
\hline Freight & \\
Unexpected items & 26.11 \\
\hline Total Direct Costs & 18,304 & \\
\hline
\end{tabular}




\begin{tabular}{|l|r|r|r|}
\multicolumn{4}{|c}{ Costs of Production: Wheat - USA } \\
\hline & $\begin{array}{r}\text { US } \$ \text { / } \\
\text { acre }\end{array}$ & US $\$$ /h. & Ch.\$/ha. \\
\hline ITEM & & & \\
Operating Costs & & & \\
Seed & 6.88 & 17 & 11,919 \\
Fertilizer & 23.93 & 59.13 & 41,458 \\
Pesticides & 7.33 & 18.11 & 12,698 \\
Hired Labour & 8.9 & 21.99 & 15,418 \\
Unpaid Labour & 16.48 & 40.72 & 28,550 \\
Fuel, lube and other & 9.26 & 22.88 & 16,042 \\
Repairs & 10.37 & 25.62 & 17,963 \\
Other variable expenses (1) & 0.62 & 1.53 & 1,073 \\
\hline DIRECT COSTS & 83.77 & 206.98 & 145,121 \\
\hline Allocated overhead: & & & \\
Depreciation (2) & 50.08 & 123.75 & 86,766 \\
*Land & 39.63 & 97.93 & 68,663 \\
*Insurance and taxes & 4.04 & 9.98 & 6,997 \\
*General indirect expenses & 7.28 & 17.99 & 12,614 \\
*Interests & 0.6 & 1.48 & 1,038 \\
\hline TOTAL ALLOCATED COSTS & 101.63 & 251.13 & 176,078 \\
\hline TOTAL COSTS & 185.4 & 458.11 & 321,199 \\
\hline TOTAL DIRECTS COSTS (3) & 98.79 & 244.11 & 171,151 \\
\hline
\end{tabular}




\begin{tabular}{|l|r|r|r|}
\hline \multicolumn{4}{c}{ Costs OF Production: Corn-USA ${ }^{2 \mathrm{~B}}$} \\
\hline & $\begin{array}{l}\text { US\$/ } \\
\text { acre }\end{array}$ & \multicolumn{1}{l}{$\begin{array}{l}\text { US } \$ \\
\text { h. }\end{array}$} & Ch.\$/h. \\
\hline ITEM & & & \\
Operating Costs & 34.45 & 85.13 & 59,688 \\
Seed & 47.62 & 117.67 & 82,503 \\
Fertilizer & 29.12 & 71.96 & 50,454 \\
Pesticides & 15.02 & 37.11 & 26,019 \\
Hired Labour & 34.24 & 84.61 & 59,323 \\
Unpaid Labour & 30.03 & 74.2 & 52,025 \\
Fuel, lube and other & 18.62 & 46.01 & 32,259 \\
Repairs & 0.32 & 0.79 & 554 \\
Other variable expenses (1) & 209.42 & 517.48 & 362,825 \\
\hline DIRECT COSTS & & & \\
\hline Allocated overhead: & 74.42 & 183.89 & 128,933 \\
Depreciation (2) & 90.33 & 223.21 & 156,501 \\
*Land & 7.5 & 18.53 & 12,992 \\
*Insurance and taxes & 11.78 & 29.11 & 20,410 \\
*General farm overhead & 1.65 & 4.08 & 2,861 \\
\hline *Interests & 185.68 & 458.82 & 321,697 \\
\hline TOTAL ALLOCATED COSTS & 395.1 & 976.3 & 684,522 \\
\hline TOTAL COSTS & 239.18 & 591.03 & 414,394 \\
\hline TOTAL DIRECTS COSTS (3) & \multicolumn{3}{|c|}{} \\
\hline
\end{tabular}

Recebido em abril de 2005 e revisto em junho de 2006

A Source: created by the author, 2003. with information from the ODEPA, INIA, Departamento de Economía Agraria Universidad de Talca, Banco Central de Chile and Revista del Campo.

BSource: USDA, 2003.

(1) Cost of purchased irrigation water.

(2) Costs of Depreciations: In the case of corn producers, $40 \%$ of the total cost of machinery depreciation was considered as a direct production cost, and $30 \%$ in the case of wheat producers.

(3) Total Directs Costs = Operating Costs plus $30-40 \%$ of the total cost of machinery depreciation (wheat and corn respectively).

$(*)$ These items were not considered for comparisons with the Chilean producers.

1 hectare $=2.4710$ acres. 1 US $\$=701.14$ Chilean pesos. 